\title{
First report of live deep-water cnidarian assemblages from the Malta Escarpment
}

\author{
L. Angeletti, A. Mecho, C. Doya, A. Micallef, V. Huvenne, A. Georgiopoulou \& \\ M. Taviani
}

To cite this article: L. Angeletti, A. Mecho, C. Doya, A. Micallef, V. Huvenne, A. Georgiopoulou \& M. Taviani (2015) First report of live deep-water cnidarian assemblages from the Malta Escarpment, Italian Journal of Zoology, 82:2, 291-297, DOI: 10.1080/11250003.2015.1026416

To link to this article: https://doi.org/10.1080/11250003.2015.1026416

\section{(.) 2015 Unione Zoologica Italiana}

\section{曲 Published online: 16 Apr 2015.}

Submit your article to this journal 지

Џ Article views: 403

Q View related articles $₫$

View Crossmark data $\nearrow$

Citing articles: 4 View citing articles 20 


\title{
First report of live deep-water cnidarian assemblages from the Malta Escarpment
}

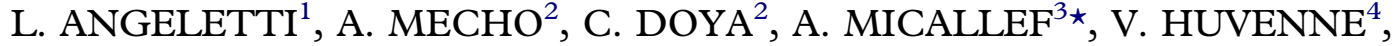 \\ A. GEORGIOPOULOU ${ }^{5}, \&$ M. TAVIANI ${ }^{1}$ \\ ${ }^{1}$ ISMAR-CNR, UOS Bologna, Italy, ${ }^{2}$ Institut de Ciències del Mar, CSIC, Passeig Marítim de la Barceloneta, Spain, \\ ${ }^{3}$ Department of Physics, Faculty of Science, University of Malta, Malta, ${ }^{4}$ National Oceanography Centre, University of \\ Southampton Waterfront Campus, United Kingdom, and ${ }^{5}$ School of Geological Sciences, Science Centre, Belfield, University \\ College Dublin, Ireland
}

(Received 27 December 2013; accepted 28 February 2015)

\begin{abstract}
A recent geo-marine survey of the Malta Escarpment revealed for the first time the existence of live cnidarian assemblages at about $300 \mathrm{~m}$ depth. These associations have been observed by means of a remotely operated vehicle (ROV) during surveys carried out on the upper part of the Malta Escarpment. The assemblages established on hard bedrock were chiefly composed of the antipatharian Leiopathes glaberrima. The Malta Escarpment is known to have been successfully colonised by deep-water scleractinian assemblages until the last glacial age. However, no living specimens had been observed, and only specimens of dead but relatively fresh Dendrophyllia cornigera had been reported. This area of the Mediterranean Sea, which connects the deep Ionian basin to the western Mediterranean, is largely unknown and in clear need of thorough exploration.
\end{abstract}

Keywords: Leiopathes glaberrima, cnidarian assemblages, Malta Escarpment, ROV, central Mediterranean

\section{Introduction}

The routine application of detailed multibeam mapping, coupled with remotely operated vehicle (ROV) inspection of promising submerged topographies, has often led to the discovery of deep-water habitats characterised by sessile megabenthic communities in the Mediterranean Sea. By and large, the most relevant actors of such aphotic communities are cnidarians and sponges associated with poorly sampled hard bottoms at depths exceeding $200 \mathrm{~m}$. This is primarily the case for the so-called white coral communities documented at bathyal depths in the Strait of Sicily, southern Adriatic, Ionian, Ligurian, Marmara, northwestern Mediterranean and Alboran seas (Tursi et al. 2004; Taviani et al. 2005a, 2005b, 2011a; Freiwald et al. 2009; Mastrototaro et al. 2010; Vertino et al. 2010; Gori et al. 2013; Angeletti et al. 2014; Fabri et al. 2014), the sponge-dominated habitats in the Tyrrhenian, Ionian and Adriatic seas (Bo et al. 2012; Calcinai et al. 2013), and antipatharian-gorgonacean communities in the Tyrrhenian, Ionian and Adriatic seas and in the Strait of Sicily (Costantini et al. 2010; Taviani et al. 2010; Bo et al. 2011; Angeletti et al. 2014; Deidun et al. 2014). From this ecological perspective, the Malta Escarpment in the central Mediterranean happens to be one of the least explored in European waters. It borders westwards the deep Ionian Sea and comprises the eastern entrance into the Strait of Sicily, both areas hosting significant deep-water coral presence (Taviani et al. 2011a). A recent ROV-assisted geo-marine survey inspected the upper part of the north Malta Escarpment, discovering for the first time live cnidarian assemblages dominated by antipatharians (black corals) in this region. The scope of this study is to describe new findings of hard-bottom assemblages present in the upper Malta Escarpment.

\section{Regional setting}

The Malta Escarpment is a dominant physiographic element in the central Mediterranean Sea

${ }^{\star}$ Correspondence: A. Micallef, Department of Physics, Faculty of Science, University of Malta, Msida, MSD 2080, Malta. Tel: +356 23403613. Fax: +356

23403613. Email: aaron.micallef@um.edu.mt

(C) 2015 Unione Zoologica Italiana 
(Figure 1a). It consists of a steep, NNW-SSE trending slope that extends southwards from the east coast of Sicily for $250 \mathrm{~km}$ with a vertical relief of up to $3.5 \mathrm{~km}$ (Biju-Duval et al. 1982, 1983; Groupe Escarmed 1982). The Malta Escarpment is the expression of a passive margin separating the continental crust of the Malta Plateau from the oceanic crust of the Ionian Basin (Argnani \& Bonazzi 2005). The age of the Malta Escarpment remains controversial, with estimates ranging from Late Triassic to Early Cretaceous (Argnani et al. 2012). Triassic-Neogene shallow-water to basinal carbonate sequences outcrop along the escarpment (Scandone et al. 1981; Casero et al. 1984). The Malta Escarpment incorporates extensional block faulting and sinistral strike-slip deformation as a result of the different rates of underthrusting between the buoyant Malta Plateau and the Ionian crust (Grasso 1993; Adam et al. 2000; Catalano et al. 2000). The Malta Escarpment can be classified as a sediment-starved margin (at least since the Messinian), with an estimated post-Messinian sedimentation rate of $\sim 6 \mathrm{~cm} \mathrm{ka}^{-1}$ (Max et al. 1993; Osler \& Algan 1999). A series of submarine canyons has been mapped from bathymetric data acquired in the late 1970s (Scandone et al. 1981). Landslide activity across the Malta Escarpment had mainly been inferred from sediment cores, with turbidites, megaturbidites and debris flows being reported from the base of the Malta Escarpment (Scandone et al. 1981; Casero et al. 1984; Rebesco et al. 2000). More recently, submarine landslides, in the form of translational slides, spreads and debris flows, have been shown to be a widespread geomorphologic phenomenon across the outer Malta Plateau and upper Malta Escarpment (Micallef et al. 2013). The outer Malta Plateau also hosts four channels and a number of straight to non-linear bedrock ridges (Micallef et al. 2013).

\section{Material and methods}

The outer Malta Plateau and upper Malta Escarpment (Figure 1a) were surveyed during the CUMECS (Canyon processes in sediment-undersupplied margins: A geomorphometric investigation of the Malta Escarpment submarine canyons) cruise (28 June-2 July 2012) on board the R/V (Research Vessel) Urania. Swath bathymetry data were acquired from $370 \mathrm{~km}^{2}$ of seafloor using a Kongsberg Simrad EM710 multibeam echosounder with a nominal sonar frequency of 70-100 kHz (Micallef et al. 2013). An ROV dive was carried out to obtain video footage and still photographs of small-scale morphology, benthic habitats and biota from the canyon heads in order to ground-truth the acoustic data. The ROV carried a forward-looking $1 / 3$ " Sony CCD (charge coupling device) colour video camera placed inside the pod. Video frames of the seabed described in the present study were acquired along one transect on the upper Malta Escarpment (Figure 2; Table I). The survey lasted approximately $5 \mathrm{~h}$. The covered distance was ca. $2.7 \mathrm{~km}$ and the depth range surveyed was from 300 to $537 \mathrm{~m}$ depth. One bottom sampling was carried out across a non-linear bedrock ridge using a rock dredge to allow the correct taxonomic identification of the species observed by ROV (Table I).

\section{Results}

ROV imagery shows a general habitat covered with a thick drape of fine-grained sediment displaying a wide variety of bioturbation features. Sedimentary bottoms of the shelf edge and upper slope (300-310 m) were colonised by octocorals such as Funiculina quadrangularis (Pallas, 1766) (Figure 2). Fish fauna included the trumpet fish, Macroromphosus scolopax (Linnaeus, 1758), Helicolenus dactylopterus (Delaroche, 1809), Lepidopus caudatus (Euphrasen, 1788), Polyprion americanus (Bloch and Schneider, 1801) and Naucrates ductor (Linnaeus, 1758).

The ROV dive showed the presence of antipatharian assemblages on a bedrock ridge of the Malta Escarpment, where large colonies of two different black coral species, Leiopathes glaberrima (Esper, 1788) and Antipathes dichotoma (Pallas, 1776), were observed at depths of 310-315 m (Figure 2). Colonies are sparsely distributed along the ROV track, although $L$. glaberrima dominates over $A$. dichotoma. Most of the colonies appeared healthy, although some showed signs of degradation. L. glaberrima branches hosted decapods (i.e. Anamathia rissoana Roux, 1828), barnacles (i.e. Verruca sp.) and other unidentified fauna.

Somewhat deeper (342 m depth), gorgonians (e.g. cf. Paramuricea macrospina) and encrusting yellow and blue hexactinelliid sponges were found. Vagile benthos included crustaceans (i.e. Munida tenuimana Sars, 1872) and echinoids (i.e. Cidaris cidaris Linnaeus, 1758)

Along the transect we observed several linear elongate depressions on the sediment surface, which we interpret as trawl marks, as well as lost fishing gear snagged around the rock outcrops.

Dredged material from one of these escarpments consists of carbonate hardgrounds.

\section{Discussion}

The high, steep and sediment-starved flanks of the Malta Escarpment are ideal sites for the formation of hardgrounds, which also served as 

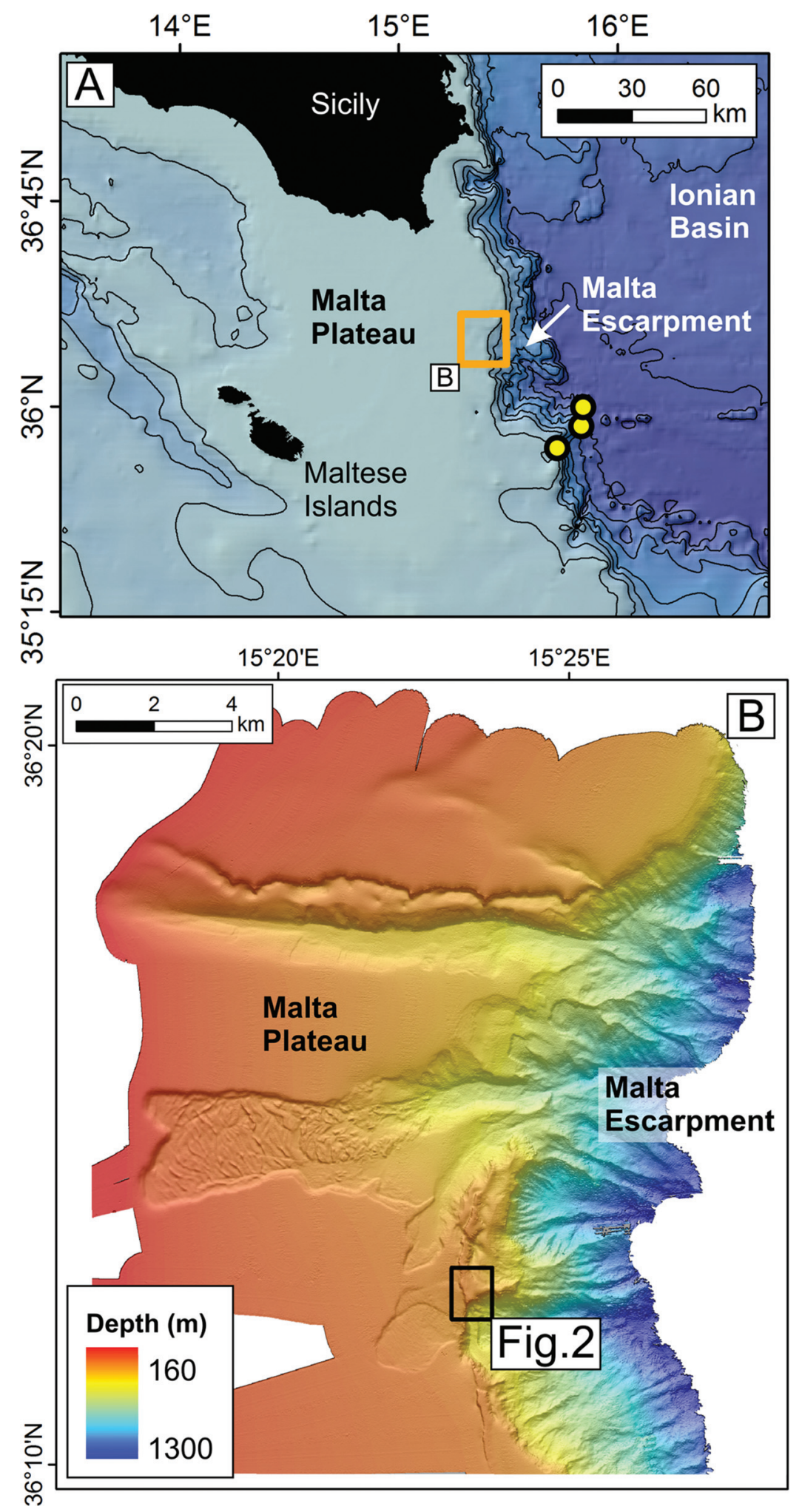

Figure 1. (A) Bathymetric map of the Malta Escarpment, central Mediterranean Sea (Source: IOC et al. 2003). The yellow dots indicate the locations of glacial Pleistocene deep-water coral hardgrounds found during previous campaigns (Taviani \& Colantoni 1984). (B) Detailed multibeam bathymetric data of the upper Malta Escarpment, acquired during the CUMECS cruise, where the live cnidarian-dominated assemblages were discovered. 


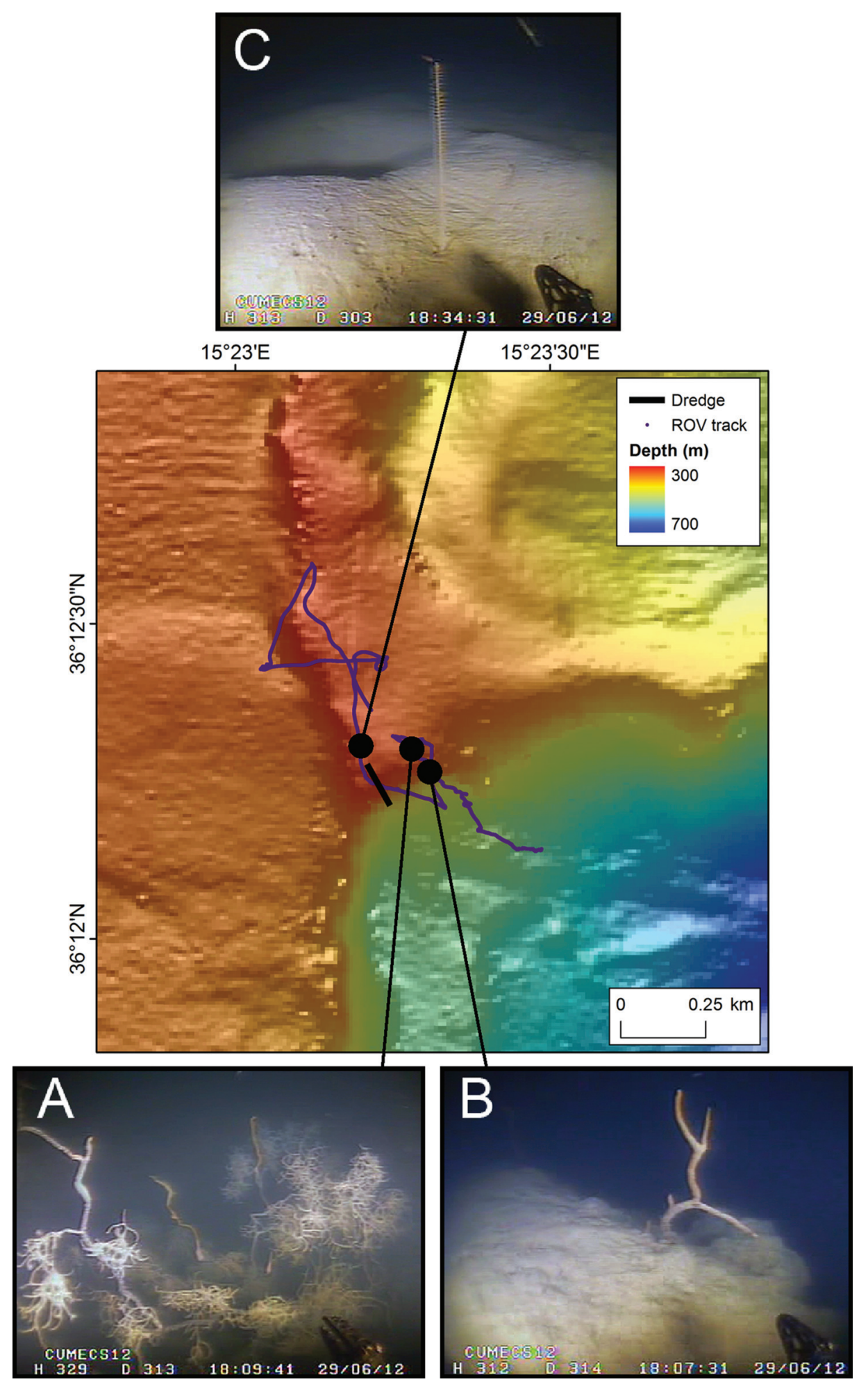

Figure 2. Detail of the Malta Escarpment showing the track of remotely operated vehicle (ROV) dive and dredge with photos of emblematic cnidarians: (A) most dense aggregation of the antipatharian Leiopathes glaberrima (313 m depth); (B) moribund/dead stalk of black coral (314 m depth); (C) a specimen of the octocoral Funiculina quadrangularis, a common inhabitant of deep-sea muddy bottoms (303 $\mathrm{m}$ depth).

substrate to a variety of encrusting organisms and sessile megabenthos since at least the Pleistocene (Biju-Duval et al. 1983; Allouc 1986, 1990). As such, the escarpment has also been episodically colonised by deep-water corals and other macrobenthic epifauna. This is proven by abundant 
Table I. Location and depth of the remotely operated vehicle (ROV) track and dredge station discussed in text. The track of the ROV dive is not a straight line going from deep to shallow, but an irregular line that at some points covered seabed shallower than the $325 \mathrm{~m}$ at the final point (e.g. one of the shallowest areas explored was at $310 \mathrm{~m}$ where Leiopathes glaberrima was found).

\begin{tabular}{|c|c|c|c|c|c|}
\hline \multicolumn{3}{|c|}{ Start } & \multicolumn{3}{|c|}{ Finish } \\
\hline Latitude & Longitude & Depth & Latitude & Longitude & Depth \\
\hline \multicolumn{6}{|l|}{ ROV track } \\
\hline $36.202349^{\circ} \mathrm{N}$ & $15.391455^{\circ} \mathrm{E}$ & $537 \mathrm{~m}$ & $36.206037^{\circ} \mathrm{N}$ & $15.386949^{\circ} \mathrm{E}$ & $325 \mathrm{~m}$ \\
\hline \multicolumn{6}{|l|}{ Dredge track } \\
\hline $36.203519^{\circ} \mathrm{N}$ & $15.387432^{\circ} \mathrm{E}$ & $415 \mathrm{~m}$ & $36.204625^{\circ} \mathrm{N}$ & $15.386820^{\circ} \mathrm{E}$ & $319 \mathrm{~m}$ \\
\hline
\end{tabular}

skeletal remains of scleractinians dredged and observed by submersible dives at depths exceeding $2000 \mathrm{~m}$ during Italian and French missions in the 1980s (Cita et al. 1979, 1980; Taviani \& Colantoni 1984). None of the observed organisms had been proven to be alive. By and large, deepwater corals are represented by well-preserved, still- aragonitic sub-fossil corallites embedded into micritic authigenic crusts, the external surfaces of which are patinated by manganese (Mn)iron (Fe) oxides (Taviani \& Colantoni 1984). A distinct assemblage dominated by the cosmopolitan solitary taxon Desmophyllum dianthus (Esper, 1794), with minimal intermixing with colonial species, was identified between 2500 and $3500 \mathrm{~m}$. Coral rubbles of Dendrophyllia cornigera (Lamarck, 1816) were present at such depths, but no live colonies had been observed. These subfossil corals have been dated to the last glacial age (Delibrias \& Taviani 1985), and represent a distinct deep-water coral assemblage that inhabited the Mediterranean Sea during the glacial Pleistocene. Such assemblages have mostly been reported at considerable depths in the Mediterranean basin (e.g. Eastern Mediterranean Basin, Zibrowius 1981; Taviani et al. 2011b).

Our study produces evidence that sessile megabenthos, especially the black coral Leiopathes glaberrima, forms live assemblages at shallower depths in association with gorgonians, and confirms their cosmopolitan distribution in the Mediterranean waters at depths down to $300 \mathrm{~m}$ (e.g. Bo et al. 2009; Deidun et al. 2010; Angeletti et al. 2014; Deidun et al. 2014). In some cases, L. glaberrima provides a habitat for commercially important crustaceans, as reported in the Atlantic and Pacific Oceans (e.g. Le Guilloux et al. 2010; Cañete \& Haussermann 2012).

To the best of our knowledge, no information on living deep-water scleractinian corals on the Malta Escarpment was available until the present study. This is puzzling, considering the fact that live colonies of deep-water corals such as Lophelia pertusa (Linnaeus, 1758), Madrepora oculata (Linnaeus, 1758), Dendrophyllia cornigera (Lamarck, 1816) and the solitary coral Desmophyllum dianthus (Esper, 1794) have been well documented in the Strait of Sicily and elsewhere in the Ionian Sea, at depths comparable to those in the present study (Schembri et al. 2007; Freiwald et al. 2009; Angeletti \& Taviani 2011; Taviani et al. 2011a). Most occurrences in our study area often referred to dead pre-modern material (e.g. Fink et al. 2012; McCulloch et al. 2012). Nevertheless, it seems unlikely that the Malta Escarpment as a whole would be deprived of such cnidarians. Our discovery of living antipatharians may suggest that the absence of deep-water coral reports in this area could be the result of the paucity of studies carried out on the Malta Escarpment. Our results stress the need to increase the geo-marine sampling effort across the Malta Escarpment for a more complete assessment of biodiversity in the central Mediterranean basin.

\section{Acknowledgements}

We are indebted to officers, crew and the shipboard party for their cooperation during the CUMECS cruise. This research was supported by funding from the Union Seventh Framework Programme (FP7/2007-2013) under grant agreements no. 228344 (EUROFLEETS), no. 252702 (CAGE) and no. 618149 (SCARP), and ERC Starting Grant no. 258482 (CODEMAP). This paper contributes to RITMARE and EU CoCoNet projects, and is ISMAR-CNR scientific contribution no. 1826.

\section{References}

Adam J, Reuther C-D, Grasso M, Torelli L. 2000. Active fault kinematics and crustal stresses along the Ionian margin of southeastern Sicily. Tectonophysics 326:217-239. doi:10.1016/S0040-1951(00)00141-4. 
Allouc J. 1986. Les encroutements sous-marins de Méditerranée orientale: une explication génétique. Revue de l'Institute Français du Pétrole 41:351-376.

Allouc J. 1990. Quaternary crusts on slopes of the Mediterranean Sea: A tentative explanation for their genesis. Marine Geology 94:205-238. doi:10.1016/0025-3227(90)90070-Z.

Angeletti L, Taviani M. 2011. Entrapment, preservation and incipient fossilization of benthic predatory molluscs within deepwater coral frames in the Mediterranean Sea. Geobios 44: 543-548. doi:10.1016/j.geobios.2011.02.004.

Angeletti L, Taviani M, Canese S, Foglini F, Mastrototaro F, Argnani A, Trincardi F, Bakran-Petricioli T, Ceregato A, Chimienti G, Mačić V, Poliseno A. 2014. New deep-water cnidarian sites in the southern Adriatic Sea. Mediterranean Marine Science 15:263-273. doi:10.12681/mms.558.

Argnani A, Armigliato A, Pagnoni G, Zaniboni F, Tinti S, Bonazzi C. 2012. Active tectonics along the submarine slope of southeastern Sicily and the source of the 11 January 1693 earthquake and tsunami. Natural Hazards and Earth System Sciences 12:1311-1319. doi:10.5194/nhess-12-1311-2012.

Argnani A, Bonazzi C. 2005. Malta Escarpment fault zone offshore eastern Sicily: Pliocene-Quaternary tectonic evolution based on new multichannel seismic data. Tectonics 24: TC4009. doi:10.1029/2004TC001656.

Biju-Duval B, Morel Y, Baudrimont A, Bizon G, Bizon JJ. 1982. Données nouvelles sur les marges du Bassin Ionien profond (Méditerranée Orientale). Résultats des campagnes Escarmed. Oil \& Gas Science and Technology 37:713-732. doi:10.2516/ ogst: 1982036 .

Biju-Duval B, Morel Y, Baudrimont A, Bizon G, Bizon JJ. 1983. Exemples de sédimentation condensée sur les escarpements de la mer Ionienne (Méditerranée orientale). Observations à partir du submersible Cyana. Oil \& Gas Science and Technology 38:427-438. doi:10.2516/ogst:1983025.

Bo M, Bavestrello G, Canese S, Giusti M, Angiolillo M, Cerrano C, Salvati E, Greco S. 2011. Coral assemblage off the Calabrian Coast (South Italy) with new observations on living colonies of Antipathes dichotoma. Italian Journal of Zoology 78:231-242. doi:10.1080/11250001003652619.

Bo M, Bavestrello G, Canese S, Giusti M, Salvati E, Angiolillo M, Greco S. 2009. Characteristics of a black coral meadow in the twilight zone of the central Mediterranean Sea. Marine Ecology Progress Series 397:53-61. doi:10.3354/meps08185.

Bo M, Bertolino M, Bavestrello G, Canese S, Giusti M, Angiolillo M, Pansini M, Taviani M. 2012. Role of deep sponge grounds in the Mediterranean Sea: A case study in southern Italy. Hydrobiologia 687:163-177. doi:10.1007/s10750-011-0964-1.

Calcinai B, Moratti V, Martinelli M, Bavestrello G, Taviani M. 2013. Uncommon sponges associated with deep coral bank and maerl habitats in the Strait of Sicily (Mediterranean Sea). Italian Journal of Zoology 80:412-423. doi:10.1080/ 11250003.2013 .786763$.

Cañete JI, Haussermann V. 2012. Colonial life under the Humboldt Current System: Deep-sea corals from O'Higgins I seamount. Latin American Journal of Aquatic Research 40:467-472. doi:10.3856/vol40-issue2-fulltext-23.

Casero P, Cita MB, Croce M, De Micheli A. 1984. Tentativo di interpretazione evolutiva della scarpata di Malta basata su dati geologici e geofisici. Memorie della Società Geologica Italiana 27:233-253.

Catalano R, Doglioni C, Merlini S. 2000. On the Mesozoic ionian basin. Geophysical Journal International 143:1-24.

Cita MB, Benelli F, Biggiogero B, Chezar H, Colombo A, Fantini Sestini N, Freeman-Lynde R, Iaccarino S, Jadoul F, Legnani R, Malinverno A, Massiotta P, Paggi L, Premoli-Silva I. 1980.
Contribution to the geological exploration of the Malta Escarpment (eastern Mediterranean). Rivista Italiana di Paleontologia e Stratigrafia 86:317-356.

Cita MB, Fantini Sestini N, Salvatorini G, Mazzei R, Kidd RB. 1979. Late Neogene sediments and fossils from the Malta Escarpment and their geodynamic significance. Annales Géologique des Pays Hellenique 1:273-283.

Costantini F, Taviani M, Remia A, Pintus E, Schembri PJ, Abbiati M. 2010. Deep-water Corallium rubrum (L., 1758) from the Mediterranean Sea: Preliminary genetic characterisation. Marine Ecology 31:261-269. doi:10.1111/j.1439-0485.2009.00333.x.

Deidun A, Andaloro F, Bavestrello G, Canese S, Consoli P, Micallef A, Romeo T, Bo M. 2014. First characterisation of a Leiopathes glaberrima (Cnidaria: Anthozoa: Antipatharia) forest in Maltese exploited fishing grounds. Italian Journal of Zoology 1-10. 10.1080/11250003.2014.986544.

Deidun A, Tsounis G, Balzan F, Micallef A. 2010. Records of black coral (Antipatharia) and red coral (Corallium rubrum) fishing activities in the Maltese Islands. Marine Biodiversity Records 3. 10.1017/S1755267210000709.

Delibrias G, Taviani M. 1985. Dating the death of Mediterranean deep-sea scleractinian corals. Marine Geology 62:175-180. doi:10.1016/0025-3227(84)90062-8.

Fabri M-C, Pedel L, Beuck L, Galgani F, Hebbeln D, Freiwald A. 2014. Megafauna of vulnerable marine ecosystems in French mediterranean submarine canyons: Spatial distribution and anthropogenic impacts. Deep Sea Research Part II: Topical Studies in Oceanography 104:184-207. doi:10.1016/j. dsr2.2013.06.016.

Fink HG, Wienberg C, Hebbeln D, McGregor HV, Schmiedl G, Taviani M, Freiwald A. 2012. Oxygen control on Holocene cold-water coral development in the eastern Mediterranean Sea. Deep Sea Research Part I: Oceanographic Research Papers 62:89-96. doi:10.1016/j.dsr.2011.12.013.

Freiwald A, Beuck L, Rüggeberg A, Taviani M, Hebbeln D. R/V Meteor Cruise M70- 1 Participants. 2009. The white coral community in the central Mediterranean Sea revealed by ROV surveys. Oceanography 22:58-74. doi:10.5670/ oceanog.2009.06.

Gori A, Orejas C, Madurell T, Bramanti L, Martins M, Quintanilla E, Marti-Puig P, Lo Iacono C, Puig P, Requena S, Greenacre M, Gili JM. 2013. Bathymetrical distribution and size structure of cold-water coral populations in the Cap de Creus and Lacaze-Duthiers canyons (northwestern Mediterranean). Biogeosciences 10:2049-2060. doi:10.5194/ bg-10-2049-2013.

Grasso M. 1993. Pleistocene structures along the Ionian side of the Hyblean Plateau (SE Sicily): Implications for the tectonic evolution of the Malta Escarpment. In: Max MD, Colantoni P, editors. Geological development of the Sicilian-Tunisian platform. Urbino: UNESCO. pp. 49-54.

Groupe Escarmed. 1982. Observations geologiques effectuées sur les escarpements ioniens (resultats preliminaires). Oceanis 8:637-643.

IOC, IHO, and BODC. 2003. Centenary Edition of the GEBCO Digital Atlas, published on CD-ROM on behalf of the Intergovernmental Oceanographic Commission and the International Hydrographic Organization as part of the General Bathymetric Chart of the Oceans. Liverpool, UK: British Oceanographic Data Centre.

Le Guilloux E, Hall-Spencer JM, Söffker MK, Olu K. 2010. Association between the squat lobster Gastroptychus formosus and cold-water corals in the North Atlantic. Journal of the Marine Biological Association of the United Kingdom 90:1363-1369. doi:10.1017/S0025315410000524. 
Mastrototaro F, D’Onghia G, Corriero G, Matarrese A, Maiorano P, Panetta P, Gherardi M, Longo C, Rosso A, Sciuto F, Sanfilippo R, Gravili C, Boero F, Taviani M, Tursi A. 2010. Biodiversity of the white coral bank off Cape Santa Maria di Leuca (Mediterranean Sea): An update. Deep-Sea Research Part II: Topical Studies in Oceanography 57:412-430. doi:10.1016/j.dsr2.2009.08.021.

Max MD, Kristensen A, Michelozzi E. 1993. Small scale PlioQuaternary sequence stratigraphy and shallow geology of the west-central Malta Plateau. In: Max MD, Colantoni P, editors. Geological development of the Sicilian-Tunisian platform. Urbino: UNESCO. pp. 117-122.

McCulloch M, Falter J, Trotter J, Montagna P. 2012. Coral resilience to ocean acidification and global warming through $\mathrm{pH}$ up-regulation. Nature Climate Change 2:623-627. doi: $10.1038 /$ nclimate 1473 .

Micallef A, Georgiopoulou A, Le Bas T, Mountjoy JJ, Huvenne V, Lo Iacono C. 2013. The Malta-Sicily Escarpment: Mass movement dynamics in a sediment- undersupplied margin. In: Krastel S, Berhmann JH, Volker D, Stipp M, Berndt C, Urgeles R, Chaytor JD, Huhn K, Strasser M, Harbitz CB, editors. Submarine mass movements and their consequences. Switzerland: Springer International Publishing. pp. 317-328.

Osler J, Algan O. 1999. A high resolution seismic sequence analysis of the Malta Plateau. Saclantcen Report, Serial no: SR311.

Rebesco M, Della Vedova B, Cernobori L, Aloisi G. 2000. Acoustic facies of Holocene megaturbidites in the Eastern Mediterranean. Sedimentary Geology 135:65-74. doi:10.1016/S0037-0738(00)00063-4.

Scandone P, Patacca E, Radoicic R, Ryan WBF, Cita MB, Rawson M, Chezar H, Miller E, McKenzie J, Rossi S. 1981. Mesozoic and Cenozoic rocks from Malta Escarpment (Central Mediterranean). American Association of Petroleum Geologists Bulletin 65:1299-1319.

Schembri PJ, Dimech M, Camilleri M, Page R. 2007. Living deep-water Lophelia and Madrepora corals in Maltese waters (Strait of Sicily, Mediterranean Sea). Cahiers de Biologie Marine 48:77-83.

Taviani M, Angeletti L, Antolini B, Ceregato A, Froglia C, LópezCorrea M, Montagna P, Remia A, Trincardi F, Vertino A. 2011a. Geo-biology of Mediterranean Deep-Water Coral Ecosystems. CNR@Sea:705-720.
Taviani M, Colantoni P. 1984. Paléobiocoenoses profondes à scléractiniaires sur l'escarpement de Malte-Syracuse (Mer Méditerranée) : leur structure, leur âge et leur signification. Oil \& Gas Science and Technology 39:547-559. doi:10.2516/ ogst: 1984032 .

Taviani M, Freiwald A, Beuck L, Angeletti L, Remia A, Vertino A, Dimech M, Schembri PJ. 2010. The deepest known occurrence of the precious red coral Corallium rubrum (L. 1758) in the Mediterranean Sea. In: Bussoletti E, Cottingham D, Bruckner A, Roberts G, Sandulli R, editors. Proceedings of the International Workshop on Red Coral Science, Management, and Trade: Lessons from the Mediterranean. NOAA Technical Memorandum CRCP-13. Silver Spring, MD: NOAA. pp. 87-93.

Taviani M, Freiwald A, Zibrowius H. 2005a. Deep coral growth in the Mediterranean Sea: An overwiev. In: Freiwald A, Roberts JM, editors. Cold-water Corals and Ecosystems. Berlin Heidelberg: Springer-Verlag. pp. 137-156.

Taviani M, Remia A, Corselli C, Freiwald A, Malinverno E, Mastrototaro F, Savini A, Tursi A. 2005b. First geo-marine survey of living cold-water Lophelia reefs in the Ionian Sea (Mediterranean basin). Facies 50:409-417. doi:10.1007/ s10347-004-0039-0.

Taviani M, Vertino A, López-Correa M, Savini A, De Mol B, Remia A, Montagna P, Angeletti L, Zibrowius H, Alves T, Salomidi M, Ritt B, Henry P. 2011b. Pleistocene to recent scleractinian deep-water corals and coral facies in the Eastern Mediterranean. Facies 57:579-603. doi:10.1007/s10347-0100247-8.

Tursi A, Mastrototaro F, Matarrese A, Maiorano P, D’Onghia G. 2004. Biodiversity of the white coral reefs in the Ionian Sea (central Mediterranean). Chemistry and Ecology 20:107-116. doi:10.1080/02757540310001629170.

Vertino A, Savini A, Rosso A, Di Geronimo I, Mastrototaro F, Sanfilippo R, Gay G, Etiope G. 2010. Benthic habitat characterization and distribution from two representative sites of the deep-water SML Coral Province (Mediterranean). Deep Sea Research Part II: Topical Studies in Oceanography 57:380-396. doi:10.1016/j.dsr2.2009.08.023.

Zibrowius H. 1981. Thanatocoenose pléistocène profonde à Spongiaires et Scléractiniaires dans la Fosse Hellenique. Journées d'études sur la systérnatique évolutive et la biogéographie en Méditerranée. Cagliari: CIESM 1980: 133-136. 